\title{
Financial Regulation, Credit Consumption And Economic Growth - An Analysis Of The National Credit Act In South Africa
}

Aregbeshola R. Adewale, University of South Africa, South Africa

\begin{abstract}
Credit consumptions are as old as human creation. Evidence suggests that more than two third of the consumer population in the developed world lives on credit, and the volume of trade credits have grown steadily over the past decade. The increase in credit consumption has hurled an unprecedented level of economic growth. However, recent strains placed on the macroeconomic fundamentals by credit mismanagement have resulted in a series of policy interventions to ensure a guided process of credit consumption. While credit consumption regulation is not a new phenomenon, the recent spates of interventions are essential to ameliorate opportunistic behaviours (such as moral hazards and adverse selection) not only among major lenders, but also among the entire market participants. This article estimates the effects of changes in regulation as regards the rate of credit consumption and ultimately, economic growth in South Africa. Using quarterly dataset from various sources between 2007 and 2012 in regression analyses, it was found that an increase in credit consumption has precipitated an increase in economic growth. The study also uncovers that the regulatory interventions by the South African government play significant roles in reducing reckless (secured) lending, during the period under consideration at the expense of an increase in unsecured lending.
\end{abstract}

Keywords: Financial Market Regulation in South Africa; Credit Consumption; Economic Growth; National Credit Act; Unsecured Lending; Short-Term Lending

\section{INTRODUCTION}

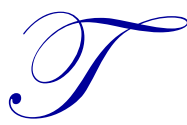

his study is conducted to evaluate the impact of the National Credit Act (NCA) on the credit consumption pattern in South Africa since its inception, and the ultimate effect of the consumption pattern on economic growth of the country. To establish the effectiveness of the Act in this regard, it is considered important to examine the trend of credit consumption in the country since 2007. While a number of public opinions abound on the impact of the National Credit Act on credit consumption in South Africa (Bloomberg, 2012; Arde, 2012; Mittner, 2013), there is no documented evidence of academic work to that effect yet. Although, there are a few policy papers on topical issues relating to the functionality of the Act (National Treasury, 2011; The National Credit Regulator, 2012). In addition, there is no documented literature on the analyses of credit consumption and economic growth since the introduction of the National Credit Act in 2005. This study intends to fill these academic lacunas by providing a scientific academic examination of the impact of the Act on credit consumption, vis-à-vis economic growth, and also by estimating the possible trend of event over a period of two years prior to the introduction of the Act (through a dynamic panel approach).

Globally, credit consumption has become an indispensable integral part of household and individual spending. Evidence suggests that credit consumption in the advanced economies have increased by more than $600 \%$ over the past two decades (Ekici \& Dunn, 2010, p. 455). As far back as 1997, more than $20 \%$ of aggregate personal consumption in the United States is conducted using credit cards (Chimerine, 1997). More specifically in 1999, the aggregate household borrowing was estimated at about US $\$ 500$ billion (Federal Reserve Board, 1999). Recent statistics on household credit consumption, especially in the advanced economies has been very high. It is estimated that credit consumption in the United States was more than US\$ 800 billion in 2004. The statistics for the other 
countries in the European Union (EU) and the rest of the world has remained in tandem with the dynamics in the US, albeit comparatively lower.

Previous studies suggest that household consumption expenditure generally stimulate economic performance, and it is seen as an important growth-driver (Prinsloo, 2002; Rajan \& Zingales, 2003). It is little surprise then, that a sharp decrease in household consumption expenditure may have a dampening effect on economic growth. Prinsloo (2002) further contends that the spending and saving behaviour of individual households is largely determined by some endogenous and exogenous factors that include social and material needs, taste and fashion, cultural and traditional inclinations, standard and cost of living, current debt to income ratio and the possibility of a future increase in aggregate income. Given these propositions, it could then be concluded that the overall household consumption expenditure is determined by the existing income/debt ratio and access of the consumers to credit (Allen \& Ndikumana, 2000). Credit extension and the regulatory environment of credit are also seen as important links in this transmission mechanism that relays changes in monetary policy to changes in the total demand for goods and services (Prinsloo, 2002).

Although, increases in credit consumption is seen as an economic growth stimulus (Rajan \& Zingales, 2003), unabated credit consumption has proven to be capable of adversely affecting economic growth as credit accumulation eventually reduces the marginal disposable household income (Ito, 1999). To strategise proactively against a potential financial crisis, regulatory interventions, essentially those that are capable of ensuring consumption smoothening, are adopted largely to curb excesses of credit consumption (The National Credit Regulator, 2012; Mittner, 2013). The recent increasing trend of personal and household bankruptcies, coupled with the financial crises that are pervading the advanced economies, is an indication that the long run marginal household consumption is bleak, and this may eventually culminate in a prolonged global economic downturn.

Literature suggests that using policy intervention in regulating economic activities remains very contentious despite its popularity (De Castro \& De Cos, 2008). The adoption of policy intervention in addressing potential explosion in a unit of national economy purportedly through exogenous behaviours has been very popular in the policy circle (Ito, 1999; Blanchard \& Perotti, 2002). Evidence abound on the use of policy intervention as the most appropriate instrument on the supply side to smoothen economic performance, especially idiosyncratic shocks in the long run (Giuliodori \& Beetsma, 2005; Corsetti \& Muller, 2006). The recent financial crises that originated from the US subprime mortgage sector, and the ultimate contagion effects on the EU economies, have resulted in a series of supply-side policy interventions not only to cushion the effects on the affected countries, but also to foreclose a possible reoccurrence. In the other parts of the world (including South Africa), similar policies had been promulgated to stabilise the financial market, especially through the demand side of the market - consumers.

The use of these forms of policy interventions in the developing world, especially in South Africa, has been more proactive than reactive. In South Africa, credit-related statutory interventions traces back to the period of the Usury Act of 1926. The Act was repealed by the Usury Act 73 of 1968. The main statutory provision of the Usury Act was to regulate the cost of capital, especially individual and household cost of credit consumption through the enforcement of the disclosure of finance charges paid by debtors, especially at individual and household levels. The main provision of the Usury Act 73 of 1968, as indicated in its preamble, reads as follows:

To provide for the limitation and disclosure of finance charges levied in respect of money lending transactions, credit transactions and leasing transactions and for matters incidental thereto; and to repeal the Usury Act, 1926.

The Act was renowned for its effectiveness and efficiency in moderating the cost of capital, especially for the necessitous that are susceptible to exploitation. The NCA 34 of 2005 became effective on 15 March 2006. The Act was enacted to address the social and economic inadequacies perpetuated by the apartheid regime, especially through imbalances in the process of awarding credit to consumers and the costs attached thereto. As suggested in the opening paragraph of the Act, the main provision of the Act was:

To promote a fair and non-discriminatory marketplace for access to consumer credit and for that purpose to provide for the general regulation of consumer credit and improve standards of consumer information; to promote black economic empowerment and ownership within the consumer credit industry; to prohibit certain unfair credit and credit-marketing practices; to promote responsible credit granting and use and for that purpose to prohibit 
reckless credit granting; to provide for debt re-organisation in cases of over-indebtedness; to regulate credit information; to provide for registration of credit bureaux, credit providers and debt counselling services; to establish national norms and standards relating to consumer credit; to promote a consistent enforcement framework relating to consumer credit; to establish the National Credit Regulator and the National Consumer Tribunal; to repeal the Usury Act, 1968 and the Credit Agreements Act, 1980; and to provide for related incidental matters.

Laying credence to the preceding paragraph, the Act was enacted to probate the government strive towards preventing reckless lending and over indebtedness of consumers. There are documented evidence, especially given the racial history of the country, that some designated groups are lured intentionally into over indebtedness (The National Credit Regulator, 2012). These set of people are exploited as the lenders capitalise on their inability (or incapacitation) to fully read, understand and digest the contents of financial contracts, being mindful of the fact that incessant consumer spending is the prime suspect for over indebtedness and default (The National Credit Act, 2005; Mittner, 2013). To ameliorate the paucity of the existing regulations, The National Credit Act was specifically promulgated to address the lingering incidence of opportunistic behaviour on the part of lenders, while at the same time cautioning excessive financial obligation on the part of consumers. The twin-aisle of the Act necessitated repealing some of the previous statutory enactments, while strengthening the existing ones concomitantly.

\section{THE MAIN PROVISIONS OF THE NATIONAL CREDIT ACT 34 OF 2005}

The Act is composed of nine chapters, 30 parts and three schedules. Chapter one Part A of the Act deals with the interpretation of the concepts and terminologies, Part B deals with the purpose of the Act and its application and Part C explains the classification and categories of credit agreements covered in the Act. Part A of the second Chapter looks at the National Credit Regulator, vis-à-vis its composition and brief. Part B explains the composition and brief of the National Consumer Tribunal as well as the remuneration of its members. Part $\mathrm{C}$ examines the administrative matters relating to the finances review of the National Credit Regulator (NCR). Part D seeks cooperation from the national and provincial government, and also seeks to facilitate information sharing among necessary organs and institutions. For the purpose of this study, the synopsis of the specific provisions of the Act that deals with credit consumption issues will be discussed.

The main provisions of the Act (consumer-related matters) are contained in Chapters three to nine. Chapter three focuses on the regulation of the entire consumer credit industry - the debt market. Part A of Chapter three provides for the requirements, processes and procedures of accrediting credit providers, while Part B provides for the compliance and cancellation of registration. Chapter four is composed of Consumer Credit Policy, with Part A dealing with consumer rights; Part B legislates on confidentiality and other credit-related information issues. Part C provides for the credit marketing policies, while Part D legislates against over indebtedness as it protects consumers from intransigent shylock lenders. The Part also contains repudiation processes. Chapter five provides for Consumer Credit Agreements of which Part A deals with credit agreements that can be regarded as being ab initio, unlawful. Part B of the Chapter provides for disclosure issues, repudiation process and the obligation of pawn brokers. Part C legislates against arbitrary financial charges and lending rates, which ultimately increases the costs of capital that in most cases, results in default and over indebtedness. Part D deals with the accuracy and adequacy of transaction records, especially the statement of account. Part E legislates against unilateral changing of any aspect of the original agreement, while Part F deals with rescission and termination of the credit agreement.

Part A of Chapter six deals with collection and repayment practices, Part B deals with the surrender of goods and the compensation of consumer, and Part $\mathrm{C}$ deals with debt enforcement - either by repossession or by judgement. Chapter seven is composed of seven parts. Part A deals with alternative dispute resolution options, Part $\mathrm{B}$ with the procedure for initiating complaints and the application of such complaints, Part $\mathrm{C}$ with information resolution or investigation of the complaints, Part D with tribunal consideration of the complaints, application and escalation of the complaints to a higher level, and Part E deals with tribunal orders.

Chapter eight deals with the enforcement of the Act, where Part A deals with statutorily-backed searches, Part B deals with related offences and the application of probable penalties. Part $\mathrm{C}$ deals with miscellaneous matters, such as agents and the requirement that credit providers are required to keep record. The last chapter (chapter nine) deals with the general provisions of the Act, consequential amendments and it concludes with the commencement of the Act. 


\section{THE EFFECTIVENESS OF THE NATIONAL CREDIT ACT 34 OF 2005 ON CREDIT CONSUMPTION}

The recent global financial crises began in the world's largest economy - the United States (US) on the $9^{\text {th }}$ day of August 2007. This was the date that one of the leading global banking groups - BNP Paribas, headquartered in Paris, with its second global headquarters in London, announced its immediate decision to cease activity in three hedge funds that specialised in United States' mortgage debt. This signals the rootage of overvalued dodgy derivatives in the global capital market, especially those that relate to the U.S mortgage sector. This announcement rattles the capital market, but the presage was not strong enough to precipitate immediate crisis. However, the uncertainty surrounding the financial value of the mortgage-related exposures, triggered an immediate distrust among banks and as a result, interbank trading receded.

According to Elliott (2011), the notion that some banks are too big to fall evaporated on the $15^{\text {th }}$ day of September, 2008 when the U.S government defied precedence of bailing out banks and allowed one of the world's leading investment banks - Lehman Brothers to file for bankruptcy. The enervating uncertainty that characterised the financial market at the time turned explosive, and the contagion effects, coupled with the bandwagon effects forced government interventions, especially in the European Union (EU) to recapitalise their banks. Although the government intervention in bank recapitalisation helped to prevent immediate collapse of the banks, it could not avert divestment in the flow of credit directed to the private sector. The level of uncertainty in the financial market extended to the sovereign debt on the $9^{\text {th }}$ of May 2010 when the IMF and the EU announced a joint decision to provide financial help to Greece. Ireland and Portugal also followed in quick succession, Spain succumbed to the unwavering bailout debacle, and the continued economic recess in Italy may eventually precipitate a bailout arrangement.

The transformation of capital market jitters from private debt crisis into a sovereign debt crisis reached its peak on the $5^{\text {th }}$ day of August 2011, when Standard \& Poor's rating agents downgraded the U.S' top-notch triple A rating. Many EU member countries, including Japan have fallen victims of the antecedents of the recent financial crises that have resulted in the economic meltdown globally. While consorted efforts are being made to arrest ultimate global recession, the root of the mortgage crises of 2007 continues to evade the weighted arms of the legislative hegemony. In South Africa however, the case has been very different. Although, the National Credit Act did not absolutely shield the economy from the contagion effects of the global financial market, the Act was able to subjugate the full-fledged impact of the crises on the real economy of the country.

The South African financial sector is the largest on the continent in both capitalisation and turnover. More specifically, the country's capital market comprises over R6 trillion in assets, and it contributes more than 10 percent to the gross domestic product of the economy yearly (National Treasury, 2011, p. 3). According to the same source, the sector employs about four percent of the active labour force and it contributes about 15 percent of the overall corporate income tax generated in 2011. As observed by Rajan and Zingales (2003), continued investor interest in a large and most efficiently ran capital market may expose the capital market to contagion effects. This futuristic orientation of the policy makers perhaps prompted the introduction of the National Credit Act in 2005.

Generally, South Africa has a rooted culture of debt rather than saving. The aggregate household debt in the country has continued to increase over the past two decades, especially among the rising black middle class (Cronje \& Roux, 2010). In South Africa, credit is seen as an important consumer need, and banks/financial institutions usually strive to satisfy these needs in order to keep existing customers and to attract new ones (Bloomberg, 2012). To ward against predatory practices and pricing on the part of lenders, and to contain reckless credit consumption on the part of the consumers, the NCA provides for the assessment of 'credit affordability' on the part of borrowers to ensure that the borrower is not over-indebted (The National Credit Regulator, 2012). This stringent disclosure clause establishes a 'red line' to measure the qualification of applicants for further credit. This specific provision of the Act, amongst others, as regards the affordability assessments of consumers has helped to safeguard reckless lending and ultimately, reckless credit consumption (The National Credit Regulator, 2012).

Although the NCA has been praised for its effectiveness in safeguarding South Africa from falling into the pit of financial distress, it has not been able to prevent opportunistic behaviour on the part of the lenders (The National Treasury, 2011; Mittner, 2013). Evidence hints that the stringent consumer assessment procedure laid down 
by the Act has created another form of credit market for shylock lenders in recent years - the unsecured lending market (The National Treasury, 2011). As a way of circumventing the provisions against opportunistic lending in the capital market, especially asset-backed finance such as home loans, the four leading banks in the country have diversified into the lower credit stream of the market (Bloomberg, 2012; Mittner, 2013). It was gathered that unsecured loans grew by more than 53\% between 2010 and 2011. While this market represented 5.7\% of the total lending in South African in 2010, it grew to $8.0 \%$ in 2011 (Bloomberg, 2012). The source further indicates that $3 / 4$ of unsecured loan consists of loans more than R15,000 and more than $60 \%$ of the loan value goes to low-middle income earners (people earning less than R10,000 per month). The most worrying aspect of the growth in unsecured loan consumption is that the loan is used for immediate consumption in most of the cases (The National Treasury, 2011; Mittner, 2013) - some applicants even use the loan to service previous debts. Although, the NCA protects consumers against opportunistic lending, indigent and more specifically, proletariat applicants largely give inadequate or misleading information about their existing credit rating in desperation of accessing these funding. Such an act automatically annuls the aspect of the Act that protects consumers against opportunistic lending (The National Credit Act, 2005).

\section{EMPIRICAL STUDY}

This study uses datasets generated from the National Credit Regulator, Statistics South Africa, and the Reserve Bank. The NCR data covers a period between the last quarter of 2007 and the third quarter of 2012 and for consistency sake; other set of data is generated for the same period. The data collection process adopted by the original source of the datasets (the databanks) attests to the reliability and accuracy of this set of data. The data is generated for various series and estimations, which have been used in previous studies (Corsetti \& Muller, 2006; De Castro \& De Cos, 2008; Ekici \& Dunn, 2010). However, because of the uniqueness of this analysis (being policyrelated estimation and dynamic nature of the issue being investigated), some macroeconomic variables (such as inflation, interest rates and economic growth) are used. These macroeconomic variables are used in combination with microeconomic variables, specifically, dataset for various credit types. However, all the data are in aggregate format.

As indicated in the introduction section, this study focuses on the effects of the National Credit Act 34 of 2005 on credit consumption in South Africa and the ultimate effect of this trend on economic growth. In order to achieve this objective, the study adopts a series of regression techniques. Apart from the test for robustness, various diagnostic measures were undertaken. Some of the diagnostics techniques are not reported, but their statistical implications are mentioned. After the diagnostic exercises, various regression analyses are conducted, and the author chooses to report the results for robust estimations only. In addition, in order to capture the dynamic nature of credit consumption pattern, dynamic regression analysis is used in the estimation.

The model specification for this study is depicted in the equation below:

Economic_Growthct $=\beta_{1}$ MORTGAGES_GRANTEDct $+\beta_{2} S E C U R E D \_C R E D I T c t+\beta_{3} S H O R T \_T E R M \_C R E D I T c t$ $+\beta_{4} U N S E C U R E D \_C R E D I T c t+\beta_{5} I N F L A T I O N c t+\beta_{6} I N T E R E S T \_R A T E S c t+u_{c t}$

Where:

Economic_growth $=$ stands for the growth rate of the economy as measured by the gross domestic product (GDP at 2005 constant prices)

Interest_Rates $=$ stands for the official interest rate, which is estimated using the repo rate

Inflation $=$ stands for the variation in the consumer price index

Mortgages_granted $=$ stands for all the home loan credit granted over the period under study

Secured_Credit $=$ is the overall credit granted based on the provision of collateral security

Short_Term_Credit $=$ is the total monetary value of credits granted for between 1 month to six months

Unsecured_Credit $=$ this means the overall financial value of credit granted over the period covered without requesting for collateral security as a prerequisite

$C=$ the categorisation of the dataset

$t=$ time 


\section{DATA ANALYSIS}

The data generated for this study is analysed using EViews statistical package (EViews 7.2). This statistical package is generally used in studies for regression analysis and diagnostics. In this analysis, the process is preceded by Unit Root Tests. The Levin, Lin, and Chu (2002) Unit Roots test was used as the dominant method, given that the dataset is arranged in panel form.

The Levin, Lin and Chu (2002) Unit Roots test (LLC) is very popular in the literature and it is regarded as the most reliable test in panel data because the technique "allows for fixed effects, individual deterministic trends and heterogeneous serially correlated errors" (Baltagi, 2008, p. 275). This is essentially so because, according to Baltagi, the length of the time series, which is held as infinity, is crucial for determining asymptotic properties of estimators. According to this author, this approach provides a good approximation for the empirical distribution of the test statistic even in relatively small samples (for example where $\mathrm{N}$ ranges between 10 and 250 , and $\mathrm{T}$ between 25 and 250), as in the case of this study.

The fixed effects consideration is important given that we are focusing on dynamic variables, and the estimation inference is restricted to the behaviour of these variables across series. In addition, given that all the dataset generated from various databanks are pooled together in the estimation, the fixed effects diagnostic wipes out the individual effects of variables in the series. The results of the Unit Root tests (not reported), suggest that the series did not exhibit any statistical indication of the presence of Unit Root, as all the variables tested were stationary in the first difference (1\%). The Unit Root test is very essential in econometrics as it helps to identify, amongst others, seasonality in the series. In addition, the test is useful to ascertain the absence of heteroscedasticity. Further, it also lays a basis for cointegration test, which is one of the important assumptions of regression analysis (Elliott, 1998).

After the Unit Root tests, the variables were tested for serial correlation, but not before ascertaining their explanatory powers. Stepwise regression technique was adopted (not presented) to establish the roles played by the variables in the estimation. According to economic theory, interest rates adjustment and inflation do play a role in credit consumption. Premised on this theory, interest rates and inflation for the period under study were introduced into the estimation. It was found that these variables did not play any role in explaining either credit consumption or economic growth over this period. This static variation may be the result of considerably stable interest rates and inflation during this period. The variance in the dataset was almost zero, except for a few outliers during the bumpy periods between the last quarter of 2007 and the first quarter of 2008.

After the stepwise estimation, we then proceed to test for serial correlation in the estimation. Here, the Breusch-Godfrey Serial Correlation Lagrange Multiplier Test was conducted. This technique is deemed appropriate because it estimates the residuals from the specified model and the derived test statistic is used as the decision criteria. The null hypothesis is that there is no serial correlation of any order in the model. This test is preferable to the Durbin-Watson statistic because the Durbin-Watson statistic is only valid for testing serial correlation in nonstochastic explanatory variables. Further, the Durbin-Watson statistic is also known for its power only in testing for regression errors in a first-order autoregressive model. The result of the serial correlation test is presented in Table 1.

From Table 1, the F-statistics of 66 indicates that the variables in this model exhibits high predictive ability, and the probability printed to the right of the Obs*R-squared statistic (i.e. 0.0000) represents the probability that one would be incorrect if one accepts the null hypothesis of the presence of serial correlation at the $99 \%$ confidence level. The $p$-value of the model $(0.0000)$ indicates that the explanatory variables used are collectively significant in explaining the variations expressed by the dependent variable, and this asseveration is buttressed by the strong value of the Adjusted R-Squared (0.8). The analysis in Table 1 also vindicates the argument advanced for the insignificance of the control variables (Inflation and Interest rates) in this estimation. These variables are now excluded in the rest of the analyses. 
Table 1: Test of Serial Correlation

\begin{tabular}{|c|c|c|c|c|}
\hline \multicolumn{4}{|c|}{ Breusch-Godfrey Serial Correlation LM Test: } & \multirow{4}{*}{$\begin{array}{c} \\
0.0000 \\
0.0000 \\
\text { Prob. }\end{array}$} \\
\hline F-statistic & 65.63814 & \multirow{2}{*}{\multicolumn{2}{|c|}{$\begin{array}{c}\text { Prob. F(2,82) } \\
\text { Prob. Chi-Square(2) }\end{array}$}} & \\
\hline Obs*R-squared & 55.39700 & & & \\
\hline Variable & Coefficient & Std. Error & t-Statistic & \\
\hline MORTGAGES_GRANTED & $-2.27 \mathrm{E}-06$ & $5.86 \mathrm{E}-07$ & -3.870032 & 0.0002 \\
\hline SECURED_CREDIT & $-9.15 \mathrm{E}-07$ & $3.78 \mathrm{E}-07$ & -2.419223 & 0.0178 \\
\hline SHORT_TERM_CREDIT & $-7.42 \mathrm{E}-05$ & $4.41 \mathrm{E}-05$ & -1.683280 & 0.0961 \\
\hline INFLATION & -662.4197 & 1707.228 & -0.098762 & 0.9216 \\
\hline UNSECURED_CREDIT & $-3.30 \mathrm{E}-06$ & 9.72E-07 & -3.393374 & 0.0011 \\
\hline INTEREST_RATES & -1452.888 & 1105.899 & -1.313762 & 0.1926 \\
\hline $\mathrm{C}$ & 57317.75 & 17914.24 & 3.199563 & 0.0020 \\
\hline RESID(-1) & 0.697405 & 0.096094 & 7.257569 & 0.0000 \\
\hline $\operatorname{RESID}(-2)$ & 0.334761 & 0.112116 & 2.985845 & 0.0037 \\
\hline R-squared & 0.815522 & \multicolumn{2}{|c|}{ Mean dependent var } & $1.41 \mathrm{E}-10$ \\
\hline Adjusted R-squared & 0.782701 & \multicolumn{2}{|c|}{ S.D. dependent var } & 38140.86 \\
\hline F-statistic & 21.75375 & \multicolumn{2}{|c|}{ Durbin-Watson stat } & 1.989626 \\
\hline Prob(F-statistic) & 0.000000 & & & \\
\hline
\end{tabular}

After testing for serial correlation, we proceed to the test of cointegration among the variables. Cointegration test is essential in econometric estimation as it measures the extent to which the series share stochastic drift. The rate at which the average in the series change, helps to determine the statistical significance of the predictor variables used for the phenomenon under consideration. The result of the cointegration test is presented in Table 2 .

Table 2: Cointegration Test

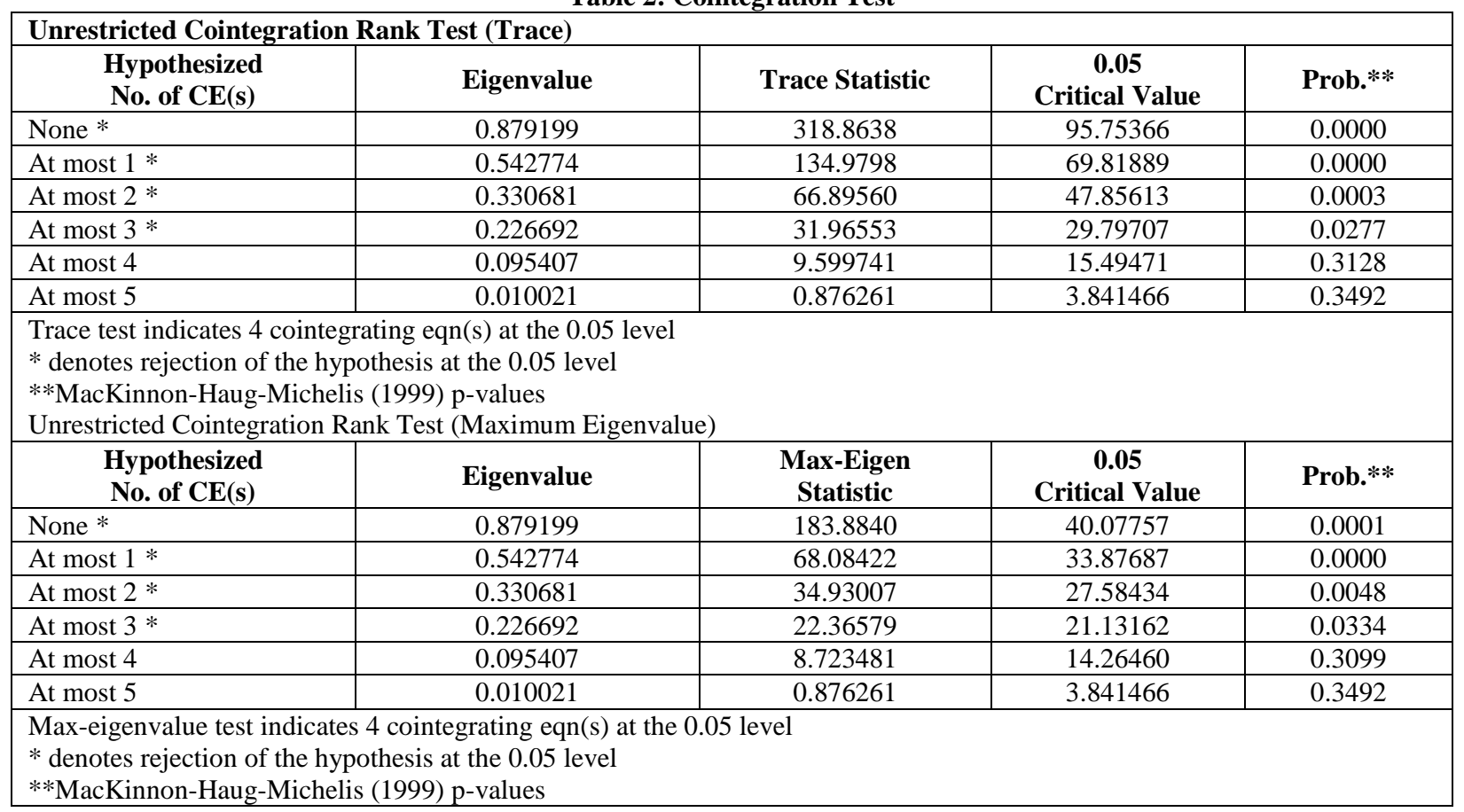

From Table 2, the test of cointegration suggests that we reject the null hypothesis of no cointegration. Using the Unrestricted Cointegration Rank Test (Trace), the result suggests that there is statistical evidence to suggest four cointegration equations at 0.05 level. Further, the Unrestricted Cointegration Rank Test (Maximum Eigenvalue) also buttresses the statistical significance of the test, and it alludes to the presence of cointegration among the variables tested as this test indicates four cointegrating equations at the $0.05 \%$ level. After the test of 
cointegration, the dynamic regression analysis was conducted. This test is intended to capture the trend of credit consumption and their effects on economic growth of the period under investigation. According to Arellano and Bond (1991), the lagged dependent variable is normally correlated with the error term. These authors contend that the errors are first-order autoregressive models, which includes individual fixed effects. This test thus accommodates seasonality errors in the estimation. The Newey-West fixed bandwidth and Bartlett Kernel standard errors and covariance matrix tests were also conducted to test for covariance and standard errors in the estimation. This test has been modified to accommodate autocorrelation in series if they exist. The result of the regression analysis is presented in Table 3.

Table 3: Generalised Method of Moment

\begin{tabular}{|l|c|c|c|c|}
\hline \multicolumn{1}{|c|}{ Variable } & Coefficient & Std. Error & t-Statistic & Prob. \\
\hline MORTGAGES_GRANTED & $2.44 \mathrm{E}-06$ & $9.38 \mathrm{E}-07$ & 2.604932 & 0.0109 \\
\hline SECURED_CREDIT & $8.38 \mathrm{E}-07$ & $8.92 \mathrm{E}-07$ & 0.939467 & 0.0502 \\
\hline SHORT_TERM_CREDIT & 0.000211 & $7.42 \mathrm{E}-05$ & 2.839289 & 0.0057 \\
\hline UNSECURED_CREDIT & $-2.27 \mathrm{E}-06$ & $1.73 \mathrm{E}-06$ & 1.316815 & 0.0005 \\
\hline C & 1833996. & 43678.29 & 41.98873 & 0.0000 \\
\hline R-squared & 0.9526323 & Mean dependent var. & 1849094. \\
\hline Adjusted R-squared & 0.8498128 & S.D. dependent var. & 55417.82 \\
\hline S.E. of regression & 39259.60 & Sum squared resid. & $1.29 \mathrm{E}+11$ \\
\hline Durbin-Watson stat & 1.783477 & \multicolumn{2}{|c|}{ J-statistic } & $1.95 \mathrm{E}-28$ \\
\hline Instrument rank & 6 & \multicolumn{2}{l}{} \\
\hline
\end{tabular}

In Table 3, all the diagnostics conducted in Table 2 are also repeated here for the sake of robustness. According to Table 3, the test of goodness of fits suggests that the estimated model exhibits a very high predictive ability. The Adjusted R-squared is 0.85 (suggesting that the variables used in the model collectively explains more than $85 \%$ of the variation expressed by the dependent variable). The J-statistic of 0.0000 , and the Durbin-Watson statistic of 1.8 all attest to the good fitness of fit of the model specified. Looking at the individual variables, all the variables used in the estimation are statistically significant, and only unsecured credit bears a negative coefficient with the regressand. The negative coefficient borne by unsecured lending suggests that this variable has a significantly negative impact on economic growth. The period analysis of these variables (that is included in the estimation, but not reported) reveals that this specific variable had been stable prior to 2007, and it has been increasing significantly since 2009 (the dependent variable is lagged twice in the estimation).

Although, the regression analyses conducted in Tables 1 to 3 are able to explain the relationships between the dependent and independent variables, it is considered important to investigate the direction of causality among these variables - hence the introduction of Granger Causality test in this study. The Granger Causality tests are generally used in estimations to examine whether there exists a long-run relationship between the macroeconomic variables under study. If there is no long-run relationship between the dependent and independent variables, then any apparent relationship suggested by the regression analysis is regarded as spurious (Baltagi, 2008). Statistically, Granger Causality from one variable $(y)$ to the coincident variable $(x)$ is established if the null hypothesis of the asymptotic chi-square $\left(\chi^{2}\right)$ test is rejected. A significant test statistic indicates that the $x$ variable has predictive value for forecasting the corresponding movements in $y$ in the series. To establish causality, the null hypothesis of no causality has to be rejected, as determined by the p-value of the series. More specifically, we reject the null hypothesis in the rows for $\mathrm{p}$-values $<=0.05$. Although one of the major shortcomings of the Granger Causality test is that it is based on the asymptotic theory, which prescribes the stationarity of variables (Granger, 1988), this assumption was satisfied in this study as contained in the pre-estimation diagnostics (the Unit Root test). The result of the Causality test is presented in Table 4. 
Table 4: Granger Causality Test

\begin{tabular}{|l|c|c|l|c|}
\hline \multicolumn{2}{|c|}{ Pairwise Granger Causality Tests } & F-Statistics & Prob. & Direction of Causality \\
\hline Serial Number & $\begin{array}{r}\text { Null Hypotheses } \\
\text { Cause GDP }\end{array}$ & 2.34224 & 0.1024 & $\neq>$ \\
\hline 1 & $\begin{array}{c}\text { GDP does not Granger Cause } \\
\text { MORTGAGES_GRANTED }\end{array}$ & 0.65062 & 0.5244 & $\neq>$ \\
\hline 3 & $\begin{array}{r}\text { SECURED_CREDIT does not Granger Cause } \\
\text { GDP }\end{array}$ & 0.85593 & 0.4286 & $\neq>$ \\
\hline 4 & $\begin{array}{r}\text { GDP does not Granger Cause } \\
\text { SECURED_CREDIT }\end{array}$ & 8.71492 & 0.0004 & $\rightarrow$ \\
\hline 5 & $\begin{array}{r}\text { SHORT_TERM_CREDIT does not Granger } \\
\text { Cause GDP }\end{array}$ & 1.80625 & 0.1707 & $\neq>$ \\
\hline 6 & $\begin{array}{r}\text { GDP does not Granger Cause } \\
\text { SHORT_TERM_CREDIT }\end{array}$ & 12.3112 & 0.0000 & $\rightarrow$ \\
\hline 7 & $\begin{array}{r}\text { UNSECURED_CREDIT does not Granger } \\
\text { Cause GDP }\end{array}$ & 8.48096 & 0.0004 & $\rightarrow$ \\
\hline 8 & $\begin{array}{r}\text { GDP does not Granger Cause } \\
\text { UNSECURED_CREDIT }\end{array}$ & 13.2692 & 0.0000 & $\rightarrow$ \\
\hline
\end{tabular}

According to Table 4, four of the expressions exhibit no causality while the remaining four exhibits causality. More importantly, only unsecured credit exhibits bidirectional causality with economic growth and this causality are significantly significant, suggesting a strong causal relationship between economic growth and unsecured credit. Looking at individual causality, the analysis contained in Table 4 suggests that economic growth does influence the amount of secured credit and short-term credits granted very significantly. The strong causality exhibits by economic growth and unsecured credit prompted further analyses, which try to establish the determinants of unsecured credit in the economy. The macroeconomic variables were used as possible determinants, while the other credit consumption variables were used as control variables. The result of the dynamic panel analyses (not presented) identifies interest rates as the only statistically significant variable in the analysis. This suggests that interest rate, which has been reducing continuously since the second quarter of 2008, strongly explains the unguided consumer appetite for unsecured credit. However, a statistical proposition on the determinants of the increasing appetite for unsecured credit (from the supply side) is difficult to prove from this estimation. The difficulty emanates from the fact that some of the variables used in previous studies (such variables include social and material needs, taste and fashion, cultural and traditional inclinations, and the possibility of a future increase in aggregate income) are subjective. Where proxies are considered possible (e.g. in measuring variables like standard and cost of living, current debt to income ratio), availability of appropriate and sufficient data pose another challenge.

\section{DISCUSSION AND CONCLUSION}

This study investigates the importance of credit consumption on the real economy. Literature suggests that an increase in credit consumption is essential to drive an increase in household consumption, which ultimately increases economic growth. Literature goes further to identify the possibility of an increase in credit, where there is prospect for an increase in household income. Aside the possibility for an increase in income, access to credit is also seen as an anecdote to increasing credit consumption. However, caution was drawn on the possibility that unchequered credit consumption may lead to over indebtedness and ultimately, overheating in the financial market. This caution necessitates policy intervention to curb excessive credit consumption, which may eventually precipitate financial crisis.

Using debt market and macroeconomic data in regression analyses, the empirical aspect of this article establishes that there is a strong relationship between increasing credit consumption and economic growth. This relationship is particularly emphasised through the causal relationship between unsecured lending and economic growth. This finding points to the fact that South Africa's imperviousness to economic recession has been strengthened by the rise in unsecured lending over time. Consequently, an argument can be advanced that the overall credit consumption in South Africa could be reduced if short-term loans (which constitute the bulk of the overall 
Rand value of the debt market) are reduced. Short-term loans are generally very profitable for lenders but they work (in most cases) against the interest of the debtors. For example, the interest rates for a six-month so-called Global One short-term loan from one of the lower-end banks (Capitec Bank) are as high as 40 percent. The case is even far upsetting with the four largest commercial banks in the country that targets up-market clients.

Also, the recent increase in unsecured loans and its possible consequences on the overall financial market is noteworthy. According to literature (The National Treasury, 2011; The National Credit Regulator, 2012), unsecured loan has the potential to trigger credit crisis whose contagion effect may ultimately precipitate economic meltdown. The bubble rising in unsecured loan is a dangerous sign of what may happen - a possible explosion in this sector of the debt market that may possibly trigger credit crunch. If this assumption holds, it may delve a devastating blow to the reeling economic recovery and growth.

Further, the time-indicative dynamic panel estimation conducted in this study suggests that unsecured loan has been increasing since 2009 while other forms of credit, especially asset-backed credits have been contracting. The fact that this line of credit has been pivotal to household consumption may be a signal to the possibility that unsecured loans are directed towards immediate household consumption. If true, inability of consumers to repay may precipitate an explosion in the financial market - the incidence of subprime mortgage sector in the United States easily comes to mind.

It may thus be suggested that unchequered increase in unsecured lending, especially given the recent increase in inflation that is transgressing beyond the targeted bracket could trigger instability in the financial market. The continued attempt at massaging the artificiality created growth, which seems to be premised largely on financial market misdemeanor, appears not to be yielding the anticipated economic dividend, especially judging from the increasing inflation that has not known any détente. It is logical to observe that financial institutions are exploiting a few of the loopholes in the National Credit Act, which prohibits them from reckless lending. Given that the confines of the NCA do not expressly cover unsecured lending, market participants are quick to explore their rent-seeking activities in a way that perpetuates their incumbency. It is essential and urgent too, to mitigate the unintended consequences of these predatory practices.

A conclusion could be drawn from the ongoing that although the NCA has been effective enough to avert the desolation of excessive and reckless credit extension to secured and asset-backed units, the need to review its practical application becomes inevitable. Arde (2012) observes that nearly half of credit consumers in the country have impaired record, and more than 6000 consumers apply for debt counselling on a monthly basis. This is a worrying sign in a country with high unemployment rate, very poorly structured unemployment safety-net, and one of the lowest savings ratios to household income. While it is almost impossible for any law to provide for all its intents, the practical application and interpretation of the Act need to be strengthened to facilitate a sustainably healthy financial market that is based on the tenets of moral judgement, professional etiquette, accountability, integrity and ethics. This done, a steady increase in household credit consumption would catalyse economic growth.

\section{AUTHOR INFORMATION}

Adewale Aregbeshola is senior lecturer at the University of South Africa. He has also held positions in the corporate and government sectors as an employee, consultant and special adviser, and has taught at various academic institutions in South Africa and abroad. Adewale's research interests are international business, globalisation, foreign direct investment, portfolio investment, global trade and investment, organisation strategy, corporate strategy and finance, African capital markets and investment. He is on the editorial board of several international journals and has a number of academic publications. He is the co-author of a few books on global business and a global report published by ACCA. E-mail: aregbra@unisa.ac.za

\section{REFERENCES}

1. Allen, D. S., \& Ndikumana, L. (2000). Financial intermediation and economic growth in Southern Africa. Journal of African Economies, 9(2), 132-160. 
2. Arde, A. (2012). Regulators all at sea while consumers drown in debt. IOL, March 25. Retrieved 03 May 2012 from http://www.iol.co.za/business/personal-finance/banking/regulators-all-at-sea-while-consumersdrown-in-debt-1.1263000

3. Arellano, M., \& Bond, S. (1991). Some tests of specification for panel data: Monte Carlo evidence and application to employment equations. Review of Economic Studies, 58(2), 277-297.

4. Baltagi, B. H. (2008). Econometrics analysis of panel data (4 ${ }^{\text {th }}$ ed.). Chichester: John Wiley and Sons Ltd.

5. Blanchard, O. J., \& Perotti, R. (2002). An empirical characterisation of the dynamic effects of changes in government spending and taxes on output. Quarterly Journal of Economics, 117(4), 1329-1368.

6. Bloomberg (UNDP - 2012). South African probes boom in unsecured lending by banks. UNDP news. Retrieved 29 April 2012 from http://www.undp.org.za/flash-news/479-south-africa-probes-boom-inunsecured-lending-by-banks

7. Chimerine, L. (1997). Americans in debt: The reality. MasterCard International.

8. Corsetti, G., \& Muller, G. J. (2006). Twin deficits: Squaring theory, evidence and common sense. Economic Policy, 21, 598-638.

9. Cronje, M., \& Roux, A. (2010). Savings culture for the black middle class in South Africa. USL Leaders' Lab, 4(2), 22-27.

10. De Castro, F., \& De Cos, P. H. (2008). The economic effects of fiscal policy: The case of Spain. Journal of Macroeconomics, 30, 1005-1028.

11. Ekici, T., \& Dunn, L. (2010). Credit card debt and consumption: Evidence form household-level data. Journal of Applied Economics, 42(4), 455-462.

12. Elliott, G. (1998). On the robustness of cointegration methods when regressors almost have unit roots. Econometrica, 66(1), 149-158.

13. Elliott, L. (2011). Global financial crisis: Five key stages: 2007-2011. From sub-prime mortgages in 2007 to the newly downgraded US debt status, the latest crisis point is unlikely to be the last. Guardian. Sunday 7. Retrieved 28 April 2012 from http://www.guardian.co.uk/business/2011/aug/07/global-financial-crisiskey-stages

14. Elliot, G., Rothenberg, J. T., \& Stock, H. J. (1996). Efficient tests for an autoregressive unit root. Econometrica, 64, 813-836.

15. Federal Reserve Board. (1999). G.19, Consumer Credit.

16. Giuliodori, M., \& Beetsma, R. (2005). What are the trade spill-overs from fiscal shocks in Europe? An empirical analysis. De Economist, 153, 167-197.

17. Granger, C. W. J. (1988). Some recent developments in the concept of causality. Journal of Econometrics, 39, 199-211.

18. Harris, R., \& Sollis, R. (2003). Applied time series modelling and forecasting. Sussex: Wiley.

19. Ito, T. (1999). Capital flows in Asia. (NBER Working Paper Series), 7134.

20. Levin, A., Lin, C., \& Chu, C.-J. (2002). Unit root tests in panel data: Asymptotic and finite-sample properties. Journal of Econometrics, 108, 1-24.

21. Mittner, M. (2013). Signs of danger. Financial Mail. Retrieved 16 May from http://www.fm.co.za/fm/CoverStory/2013/05/16/signs-of-danger

22. National Treasury. (2011). A Safer financial sector to serve South Africa better. National Treasury Policy Document; Republic of South Africa, 23 February.

23. Ng, S., \& Perron, P. (2001). Lag length selection and the construction of unit root tests with good size and power. Econometrica, 69(6), 1519-1554.

24. Prinsloo, J. W. (2002). Household debt, wealth and saving. South Africa Reserve Bank Quarterly Bulletin, 63-76.

25. Rajan, R. G., \& Zingales, L. (2003). The great reversals: The politics of financial development in the twentieth century. Journal of Financial Economics, 69, 5-50.

26. The National Credit Regulator. (2012). Research on the increase of unsecured personal loans in South Africa's credit market: Final report. 6 August.

27. The National Credit Act (NCA). (2005). No. 34 of 2005: National Credit Act, Act 2005. Government Gazette. 


\section{NOTES}

